\title{
Performance simulation of the integration of hybrid stand-alone photovoltaic system at Tuba Island
}

\author{
Shahril Irwan Sulaiman', Nur Amira Ali ${ }^{2}$ \\ ${ }^{1}$ Faculty of Electrical Engineering, Universiti Teknologi MARA, Malaysia \\ ${ }^{1,2}$ Green Energy Research Centre, Universiti Teknologi MARA, Malaysia
}

\begin{tabular}{l}
\hline Article Info \\
\hline Article history: \\
Received Jan 19, 2019 \\
Revised Apr 22, 2019 \\
Accepted May 12, 2019 \\
\hline
\end{tabular}

\section{Keywords:}

Cost of energy

Hybrid

Net present cost

Photovoltaic

Stand-alone

\begin{abstract}
Hybrid photovoltaic-diesel generator power system is important for rural electrification with the diesel generator supplying electricity when battery bank fails to meet the load demand. However, the operation of diesel generator could also be very costly due to high operation and maintenance cost when compared to photovoltaic-battery system. As a result, proper sizing must be conducted to determine the economic indicators of the hybrid photovoltaic-diesel generator system throughout its lifetime. This paper presents the design of such system for an island resort in Langkawi, Kedah, Malaysia. HOMER software was used to simulate the design parameters and economic performance of the system as compared to the existing diesel generator system. Apart from that, different capacities of PV array, battery bank and inverter were investigated in this study to determine the optimum configuration of these components such that the total cost of supplying the load demand at the resort could be minimized. The results showed that the hybrid photovoltaic-diesel generator system is more economically feasible than the existing diesel generator system used at the resort.
\end{abstract}

Copyright $@ 2019$ Institute of Advanced Engineering and Science. All rights reserved.

\section{Corresponding Author:}

Shahril Irwan Sulaiman, Faculty of Electrical Engineering, Universiti Teknologi MARA, 40450 Shah Alam, Selangor, Malaysia. Email: shahril_irwan2004@yahoo.com

\section{INTRODUCTION}

Solar electricity has been widely used not only in urban areas but also in remote areas through stand-alone photovoltaic (SAPV) systems [1]. SAPV systems offer shorter installation duration as it does not require rigorous resource assessment as in other renewable energy technologies such as wind power and hydropower. Although diesel generator systems are commonly used in remote areas without electrification from the utility grid, the operation and maintenance of such systems are very taxing due to fluctuating diesel price and challenging transportation to these remote areas. As a result, SAPV systems are often hybridized with conventional diesel generator to provide back-up electricity should the system fails or underperforms during operation [2]. These systems are known as hybrid SAPV systems.

Although the hybrid SAPV systems basically offer a technical advantage over conventional SAPV systems and diesel generator systems, the economic feasibility of running such systems must be evaluated to ensure the sustainability of electrification. Both capital and operation and maintenance costs must be considered throughout the system's operation before the hybrid SAPV system can be justified as viable mode of power supply system [3].

An optimal hybrid SAPV system was investigated for a remote village, Gwakwani, in South Africa [4]. Three stand-alone systems, i.e. photovoltaic (PV) system with a diesel generator, PV system with battery storage and PV system with diesel generator and battery storage were tested. Four different sizes of PV array, 
i.e. $1 \mathrm{~kW}, 0.0 \mathrm{~kW}, 0.6 \mathrm{~kW}$ and $0.4 \mathrm{~kW}$ were tested to meet three design criteria. The objectives are energy demand satisfaction, system cost and pollution. The results showed that PV-diesel generator with battery storage is not economically viable for the village due to the energy surplus provided by such system. In addition, the optimal system was found to be PV-battery model in terms of having lowest cost. Apart from that, a study was conducted using HOMER to optimize the cost of hybrid SAPV system for electrifying a rural health clinic in Iraq [5]. The effect of interest rate and diesel price on cost of electricity was also evaluated while the environmental benefits were quantified. However, the $31.6 \mathrm{kWh}$ daily load demand was found to be most economically supplied by an SAPV system with 9kW PV array, $80225 \mathrm{Ah}$ batteries and $3 \mathrm{~kW}$ inverter. The less expensive option is the hybrid SAPV system with a diesel generator while the most expensive option is the diesel-only generator. The Cost of Electricity (COE) as described in [6] for SAPV system, hybrid SAPV system with diesel generator and diesel-only generator are $\$ 0.238 / \mathrm{kWh}, \$ 0.272 / \mathrm{kWh}$ and $\$ 1.332 / \mathrm{kWh}$ respectively. The results emphasized that the hybrid SAPV system is not necessarily the best option and the economic feasibility must be compared and justified against other power options for a specific site. Besides that, similar study was performed to optimally design a hybrid SAPV system for a health service facility in Nkanu-West, Nigeria [7]. The results showed that the hybrid system was far more economically feasible than the diesel generator system. The hybrid system reduces dependency on fossil fuel, thus reducing the air pollution. Apart from that, another study was conducted to evaluate the economics of hybrid SAPV system for building electrification in rural oil producing communities in Nigeria [8]. The COE was found to be $\$ 0.783 / \mathrm{kWh}$. Besides that, a hybrid SAPV system was proposed to power up ATM machines in Vathar, Kolhapur, India [9]. The COE was found to be $\$ 0.307 / \mathrm{kWh}$. In addition, an SAPV system was designed using HOMER for an office building in Kwara State, Nigeria to meet two different load demands, i.e. with and without the air-conditioning loads [10]. The COE for the system without air-conditioning loads was found to be $\$ 0.539 / \mathrm{kWh}$ while the COE for system with air-conditioning loads was found to be $\$ 0.542 / \mathrm{kWh}$.

This paper presents the evaluation of economic feasibility of a hybrid SAPV system for a resort at Tuba Island, Langkawi (6 $\left.24^{\prime} \mathrm{N}, 9^{\circ} 59^{\prime} \mathrm{E}\right)$. The economic performance of the proposed hybrid SAPV system was compared with the economic performance of stand-alone diesel generator system.

\section{METHODOLOGY}

The sizing and economic analysis of the hybrid SAPV system were conducted using Hybrid Optimization of Mutiple Energy Resources (HOMER) software. The sizing process started with the declaration of daily load profile and solar irradiation profile in the software. After that, the design configuration of the system was specified. In addition, the parameters of each system component such as diesel price and cost of each component were also specified based on typical scenarios in Malaysia. Later, the operating strategies of the system are described. Daily load profile for the site as shown in Figure 1.

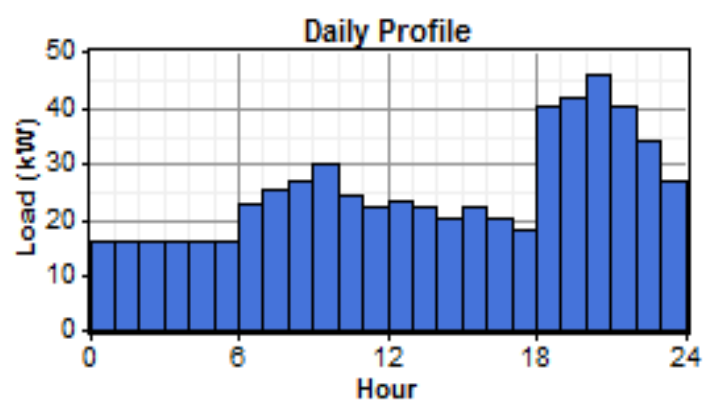

Figure 1. Daily load profile for the site

\subsection{Background information \\ 2.1.1 Load demand}

Evaluation of load demand is crucial to ensure that the solar resource is optimally used for a set of load demand [11]. Load estimation error may result in failed system in meeting load demand [12]. This study was conducted for a beach resort located in Tuba Island, Langkawi, Malaysia. The resort chalet consists of approximately 22 rooms with each room having estimated load power demand of $2 \mathrm{~kW}$ on average. Thus, the 
total maximum demand for the chalet is $44 \mathrm{~kW}$. Apart from that, the daily load demand profile for the resort is shown in Figure 1. The load usage fluctuates throughout daytime while the maximum demand occurs during nightime. The load requirement after midnight until $6 \mathrm{a} . \mathrm{m}$. is similar since the visitors of the resort are assumed to be in bed before waking up at 6 a.m. to start their leisure activities. Besides that, seasonal variation of the load demand was also considered, as depicted in Figure 2. The period with the hottest weather is identified to be from January to April. The load demand during this period is expected to be higher than usual as longer operation of air conditioners and fans are expected in the rooms. On the other hand, the rest of the months are expected to be cooler and thus lower load demand is expected. In addition, random variability of the load profile was also set. The day-to-day variability and time-step-to-time-step variability are set to be $24 \%$ respectively. The final energy demand required by the site is $433 \mathrm{kWh} /$ day or 158.045 $\mathrm{MWh} /$ year.

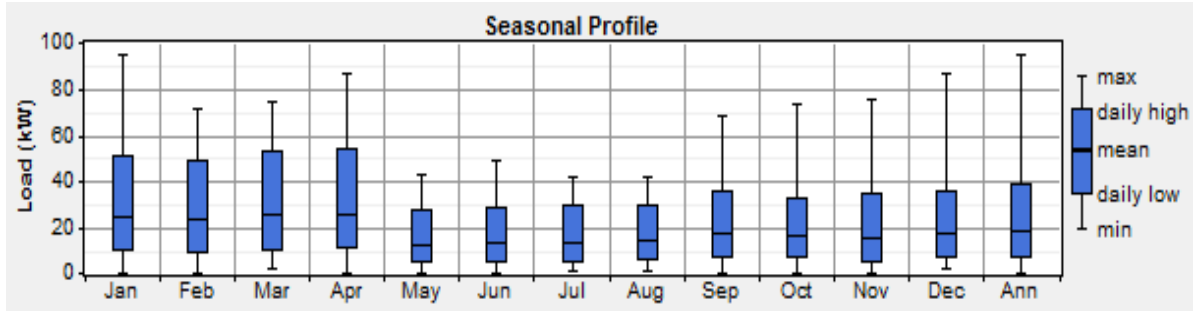

Figure 2. Monthly load profile

\subsubsection{Solar irradiation}

The performance of PV system is heavily dependent on solar irradiation and temperature [13]. Malaysia is a country that lies on the equatorial region. Its climate is governed by the regime of north-east and south-west monsoons which blows alternatively in course of the year. The transition period between these two monsoons are usually marked by heavy rainfalls. The solar irradiation profile for the site was set in HOMER by setting the corresponding Latitude and Longitude of the site, as shown in Figure 3 . The solar irradiation ranges from approximately $4.1 \mathrm{kWh} / \mathrm{m} 2$ to $6.5 \mathrm{kWh} / \mathrm{m} 2$. The scaled annual average of the solar radiation is estimated to be $4.88 \mathrm{kWh} / \mathrm{m} 2 /$ day.

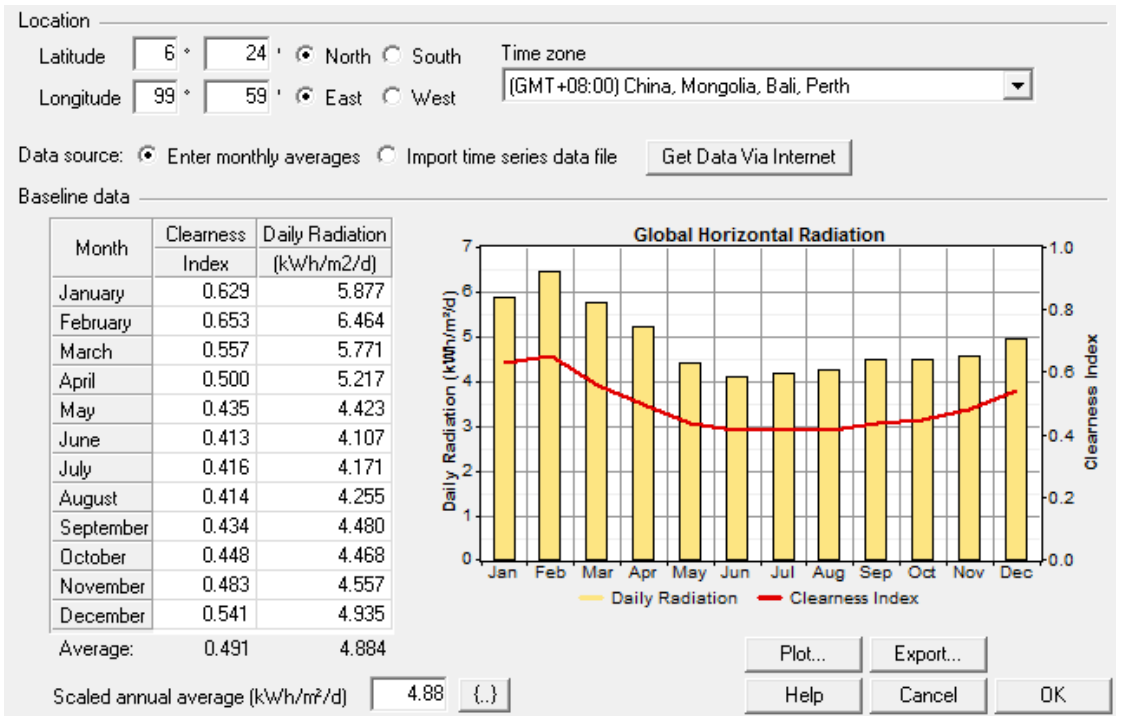

Figure 3. Solar irradiation data

\subsection{Design Specification}

HOMER software can generate itself the clearness index according to the value of solar radiation obtained. Besides that, it can be automatically generated based on the latitude of the location chosen. The

Performance simulation of the integration of hybrid stand-alone photovoltaic... (Shahril Irwan Sulaiman) 
latitude of Tuba Island is $6^{\circ} 14^{\prime} 16.6^{\prime} \mathrm{N}$. The location chosen is a remote area since the investigation is for stand-alone diesel generating system.

\subsubsection{Diesel}

Current diesel price in Malaysia is RM 1.95 per liter. However, when it is converted to US Dollar (\$), it becomes $\$ 0.53$ per liter. In 2009, AsiaOneNews [14] reported that the price of diesel is high in rural area of Sarawak. Diesel is priced at about RM 7 (\$1.95) per liter in many places of Ulu Baram district, some $200 \mathrm{~km}$ inland from Miri, Sarawak. For this simulation, the price of diesel is assumed to be $\$ 1.56$ per liter base on a currency exchange of \$ 1 equals to RM 3.20.

In this system, a hybrid SAPV system with diesel generator was proposed to replace the stand-alone diesel system at the site. The hybrid system was designed to consist of one unit of PV array, one unit of diesel generator, one unit of inverter and one unit of battery bank used to meet an AC load demand. Figure 4 illustrates the configuration of the system in details.

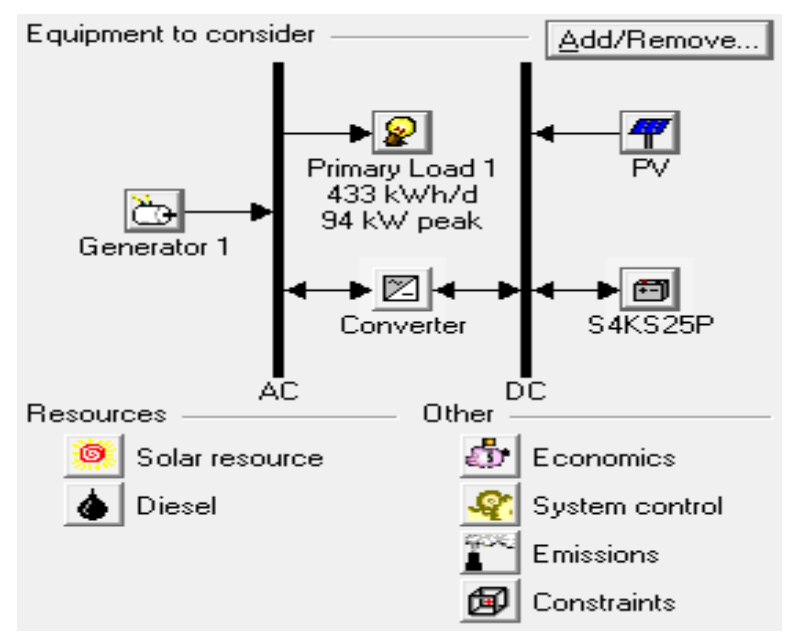

Figure 4. Configuration of the PV hybrid system

\subsubsection{Photovoltaic module}

PV module converts sunlight into DC electricity [15]. The size of PV array was set to vary from 10 $\mathrm{kW}$ to $100 \mathrm{~kW}$ such that the PV array is sufficient to meet the highest load requirement during daytime. In addition, the excess power from PV array is used to charge the battery bank.

As PV electricity is limited to daytime generation, battery or diesel generator is expected to support the load demand during nigh time. The cost index of PV module was set to be $\$ 5,000$ per $\mathrm{kWp}$ while the replacement cost of the modules was assumed to be the same as the capital cost. Operating and maintenance cost of the modules was assumed to be $\$ 250$ per year.

\subsubsection{Solar batteries}

Solar batteries are used to provide regulated electricity supply and meet the load demand based on the days of autonomy [16]. In this study, Surrette lead-acid 4KS25P batteries had been selected for the design as the lead acid batteries had been used widely in SAPV systems [17]. The minimum state of charge of this battery is $40 \%$ while its round trip efficiency is $80 \%$. The battery bank consists of 12 batteries per string. The nominal system voltage of the bank is $48 \mathrm{~V}$. The number of parallel strings of battery was varied from 1 to 10 in HOMER for determining the optimum number of strings. Besides that, the capital cost of battery was set to be $\$ 2,700$ per unit while the replacement cost was assumed to be similar to the capital cost. The operating and maintenance cost was set to be $\$ 50$ per year.

\subsubsection{Diesel generator}

The peak demand of this remote area is $94 \mathrm{~kW}$. Thus, a diesel generator with $100 \mathrm{~kW}$ peak power capacity was selected. The excess $6 \mathrm{~kW}$ from the generator capacity will cater for future load growth. The capital cost for $100 \mathrm{~kW}$ diesel generator was $\$ 25,000$ while the replacement cost for the generator was assumed to be the same as the capital cost. Operating and maintenance (O\&M) cost was set to be $\$ 7$ per 
hour. This O\&M cost was set to be at the high end of the expected cost since the location was considered to be a remote area.

\subsubsection{Inverter}

Size of inverter was chosen based on the selected PV array capacity [18]. The inverter size was varied from $10 \mathrm{~kW}$ to $100 \mathrm{~kW}$ before the optimal size was selected by HOMER. In this simulation, the efficiency of inverter was assumed to be $95 \%$. The capital cost per $\mathrm{kW}$ of inverter was assumed to be $\$ 1,000$ while the replacement cost was assumed to have the same cost as the capital cost. The operating and maintenance cost of the inverter was assumed to be $\$ 28 /$ year. Table 1 summarizes the details of the system components.

Table 1. Brief Information of the Hybrid SAPV System

\begin{tabular}{|c|c|c|c|}
\hline \multirow{2}{*}{$\begin{array}{l}\text { Description } \\
\qquad \text { PV module }\end{array}$} & Value & Description & Value \\
\hline & & \multicolumn{2}{|l|}{ Inverter } \\
\hline Capital cost & $\$ 5,000 / \mathrm{kW}$ & Capital cost & $1000 / \mathrm{kW}$ \\
\hline Replacement cost & $\$ 5,000 / \mathrm{kW}$ & Replacement cost & $1000 / \mathrm{kW}$ \\
\hline Operating and maintenance cost & $\$ 250 /$ year & Operating and maintenance cost & $\$ 28 /$ year \\
\hline Lifetime & 25 years & Lifetime & 15 years \\
\hline Battery & & Efficiency & $95 \%$ \\
\hline Capital cost & $\$ 2,700$ & \multicolumn{2}{|l|}{ Diesel generator } \\
\hline Replacement cost & $\$ 2,700$ & Size & $100 \mathrm{~kW}$ \\
\hline Operating and maintenance cost & $\$ 50 /$ year & Capital cost & $\$ 25,000$ \\
\hline Type of battery & Surrette $4 \mathrm{KS} 25 \mathrm{P}$ & Replacement cost & $\$ 25,000$ \\
\hline Nominal voltage ( 12 batteries per string) & $4 \mathrm{~V}$ (48V bus) & Operating and maintenance cost & $\$ 7 /$ hour \\
\hline Nominal capacity & $1900 \mathrm{Ah}$ & Lifetime & 15,000 hours \\
\hline State of charge & $40 \%$ & & \\
\hline
\end{tabular}

\subsection{Operating strategies}

HOMER software can model two dispatch strategies namely load following and cycle charging. For the load following strategy, generators produce just enough power to serve the load. Under cycle charging strategy, generators run at full power and charge the battery with any excess. With the cycle charging strategy, a set-point state of charge can be applied, so that the generators keep charging the battery and the battery discharge could not be left until it has reached the set-point.

In this system, load following strategy was considered [19]. Under this strategy, only PV array will charge the battery bank while generator will not charge the battery bank. Generator will only serve the load. PV array was used as the base load supply which produced DC power. The DC power will then be converted to AC power using an inverter [20]. When there was extra power after meeting the load demand, the PV array was then used to charge the battery bank. If the PV array could not meet the load demand, battery bank was discharged to cater for the demand [21-23]. If there is a case when PV array and battery bank were unable to meet the load demand, generator was automatically run to meet the demand [24].

The operating reserve as a percentage of hourly load was assumed to be $10 \%$ while the operating reserve as a percentage of solar power was assumed to be $25 \%$. Operating reserve is basically the surplus operating capacity that ensures reliability supply of electricity even if the load is suddenly increasing or renewable power output suddenly decreases. For instance, if the load at an hour is $70 \mathrm{~kW}$ and output from the $\mathrm{PV}$ array is $40 \mathrm{kWh}$, the value of the operating reserve will be $7 \mathrm{~kW}+10 \mathrm{~kW}=17 \mathrm{~kW}$. Thus, generator should provide $30 \mathrm{~kW}$ of electricity to cater for the demand in addition with the operating reserve of $17 \mathrm{~kW}$. In short, the operating capacity of the generator should be at least $47 \mathrm{~kW}$.

\section{RESULTS AND DISCUSSIONS}

The simulation was performed by comparing the use of stand-alone diesel generating system and hybrid SAPV system. The project lifetime was assumed to be 25 years with $6 \%$ annual real interest rate. The results of the comparison are shown in Figure 5. Total Net Present Cost (NPC) for stand-alone diesel system as shown in Figure 6.

\subsection{Stand-Alone Diesel System}

From simulation done by HOMER, stand-alone diesel system as described in [25] recorded the most expensive system with total Net Present Cost (NPC) of $\$ 3,746,076$. This value was obtained based on the diesel price of $\$ 1.56$ per liter. Details of the NPC are shown in Figure 6. 
Apart from that, the monthly average electricity production is shown in Figure 7. The average electricity production matches the monthly load profile as shown in Figure 2. More electricity production occurs from January to April since demand for electricity is the highest from January to April. Least electricity production occurs from May to August since electricity demand for those months is the lowest. Total electricity production was found to be $273,679 \mathrm{kWh} /$ year. This was about $100 \%$ production to meet the electricity demand. The total consumption of AC primary load was $100 \%$ which is about $158,045 \mathrm{kWh} / \mathrm{year}$. There was also $115,634 \mathrm{kWh} /$ year of excess electricity production which was about $42 \%$. The operating hours of the generator is 8753 hour/year while the fuel consumption was $138,450 \mathrm{~L} /$ year. The Cost of Energy (COE) for this system was $\$ 1.854 / \mathrm{kWh}$ while the operating cost was $\$ 291,088 /$ year.

\begin{tabular}{|c|c|c|c|c|c|c|c|c|c|c|c|c|}
\hline 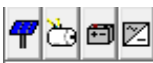 & $\begin{array}{l}\text { PV } \\
(\mathrm{kW})\end{array}$ & $\begin{array}{c}\mathrm{G} 1 \\
(\mathrm{~kW})\end{array}$ & S4KS25P & $\begin{array}{l}\text { Conv. } \\
(\mathrm{kW})\end{array}$ & $\begin{array}{l}\text { Initial } \\
\text { Capital }\end{array}$ & $\begin{array}{l}\text { Operating } \\
\text { Cost (\$/yr) }\end{array}$ & $\begin{array}{l}\text { Total } \\
\text { NPC }\end{array}$ & $\mid \begin{array}{c}\mathrm{COE} \\
(\$ / \mathrm{kWh})\end{array}$ & $\begin{array}{l}\text { Ren. } \\
\text { Frac. }\end{array}$ & $\begin{array}{l}\text { Capacity } \\
\text { Shortage }\end{array}$ & $\begin{array}{l}\text { Diesel } \\
(\mathrm{L})\end{array}$ & $\begin{array}{c}\text { G1 } \\
\text { (hrs) }\end{array}$ \\
\hline Tऽ四 & 70 & 100 & 72 & 40 & $\$ 609,400$ & 126.068 & $\$ 2,220,967$ & 1.099 & 0.53 & 0.00 & 45,362 & 2.881 \\
\hline 四 & & 100 & 60 & 20 & $\$ 207.000$ & 198,255 & $\$ 2,741,364$ & 1.357 & 0.00 & 0.00 & 89.325 & 5,653 \\
\hline$\pi$ & 80 & 100 & & 40 & $\$ 465,000$ & 244,472 & \$ $3,590,177$ & 1.777 & 0.35 & 0.00 & 105,880 & 6,689 \\
\hline 苑 & & 100 & & & $\$ 25,000$ & 291,088 & $\$ 3,746,076$ & 1.854 & 0.00 & 0.00 & 138,450 & 8.753 \\
\hline
\end{tabular}

Figure 5. Comparison between different energy systems

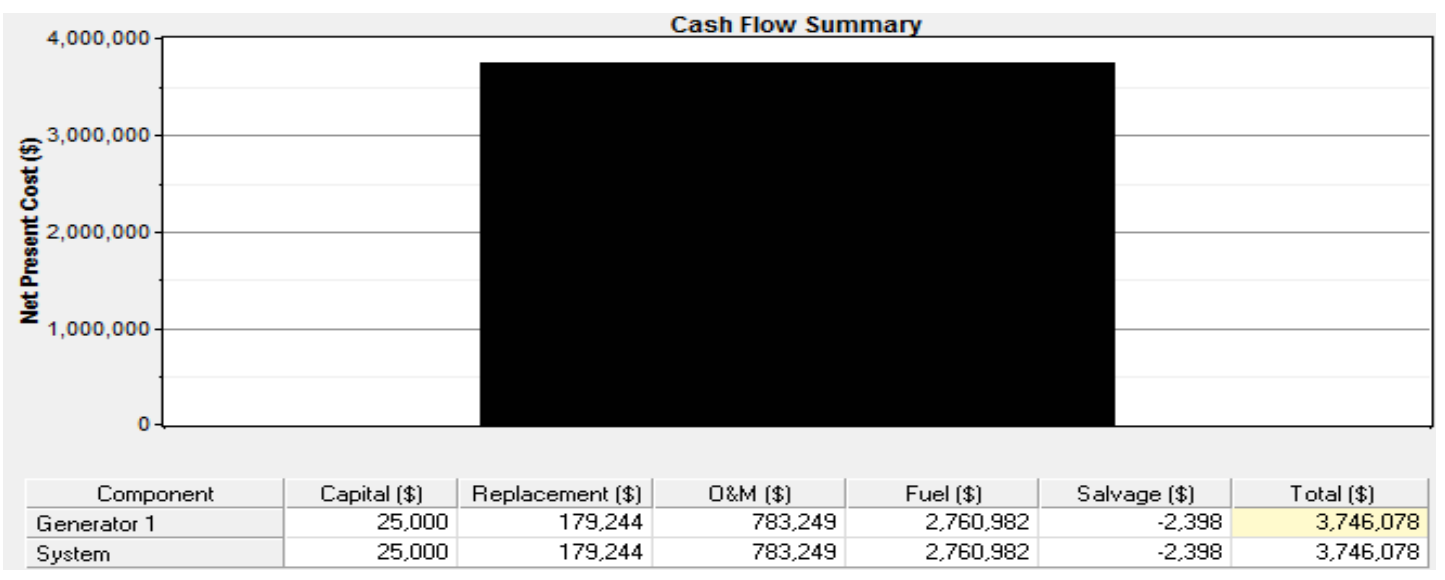

Figure 6. Total Net Present Cost (NPC) for stand-alone diesel system

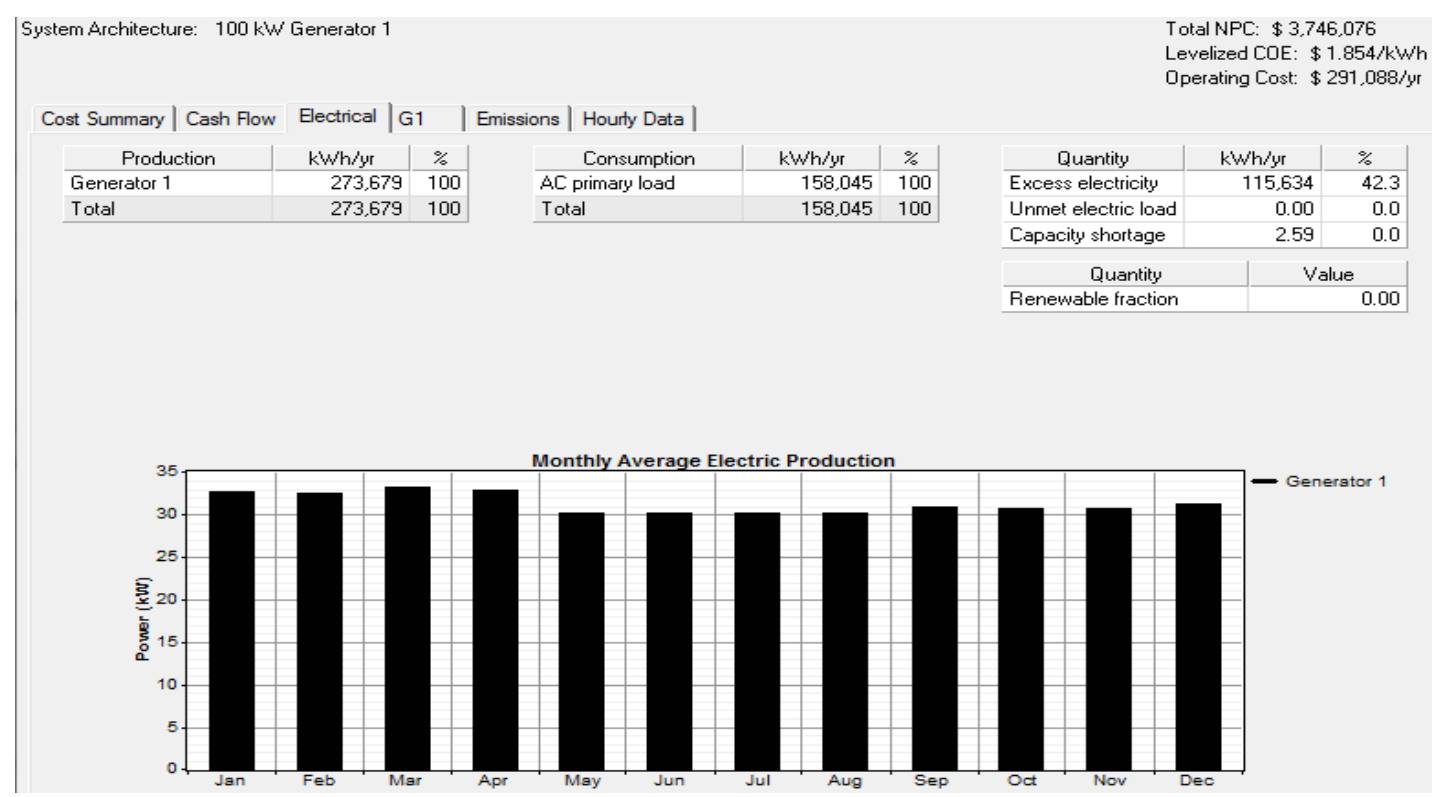

Figure 7. Monthly average electricity production for stand-alone diesel system 


\subsection{Photovoltaic hybrid system}

Based on the results shown in Figure 5, the optimal design settings was when the system is composed of $70 \mathrm{~kW} \mathrm{PV}$ array, $100 \mathrm{~kW}$ diesel generator, 72 units of battery and $40 \mathrm{~kW}$ inverter. This configuration recorded a total NPC of \$2,220,967. Details of the total NPC is shown in Figure 8.

Besides Figure 8, the monthly average electricity production is shown in Figure 9. The total combined electricity production was $189,647 \mathrm{kWh} /$ year. PV contributed about $53 \%$ to the electricity production which is approximately $100,378 \mathrm{kWh} /$ year while the electricity production by generator contributed about $47 \%$ which is approximately $89,269 \mathrm{kWh}$ /year. As the total load consumption is about $158,045 \mathrm{kWh} /$ year, there is approximately $7.04 \%$ excess of electricity production which is equivalent to $13,355 \mathrm{kWh} /$ year. The contribution of PV array to this system helped in reducing the operating hours of generator from 8753 hours/year to merely 2,881 hours/year while the fuel consumption had been reduced from $138,450 \mathrm{~L} /$ year to $45,362 \mathrm{~L} /$ year. Thus, the operating cost of the system was reduced to $\$ 126,028 /$ year. In addition, COE of the system had been reduced from $\$ 1.854 / \mathrm{kWh}$ to $\$ 1.099 / \mathrm{kWh}$. Therefore, the hybrid SAPV system was found to be more feasible when compared to the stand-alone diesel system for the electrification of the site.

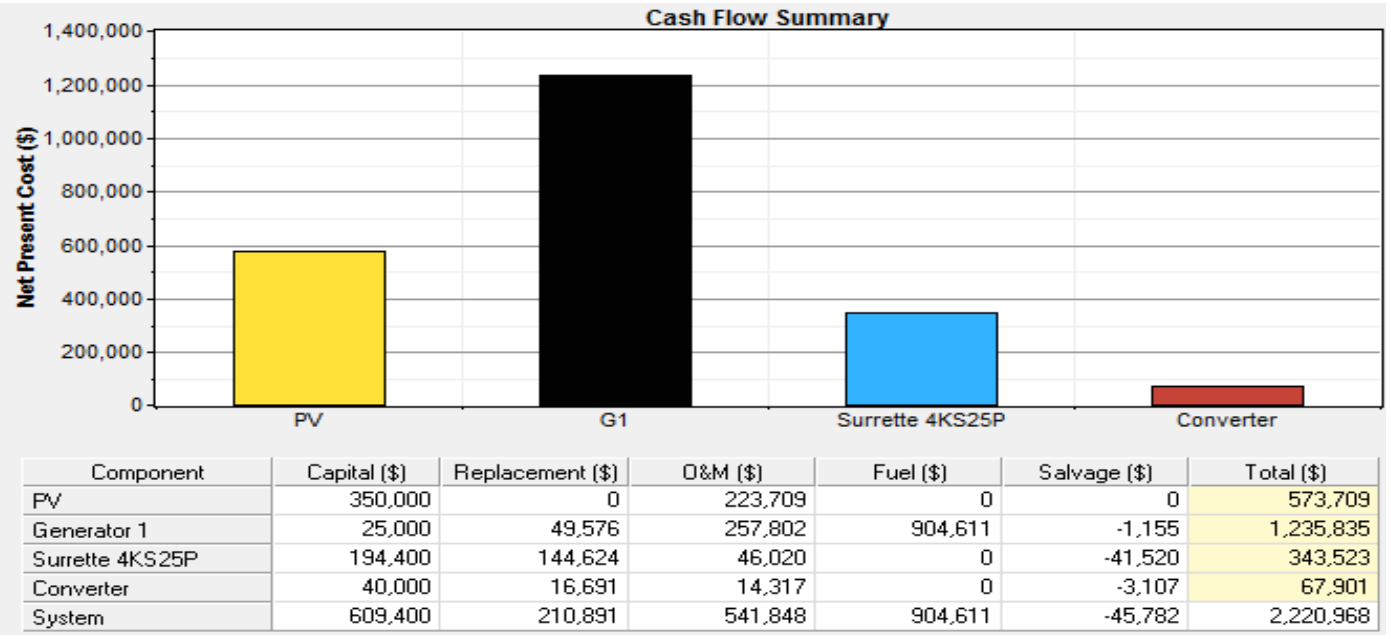

Figure 8. Total NPC for PV hybrid system

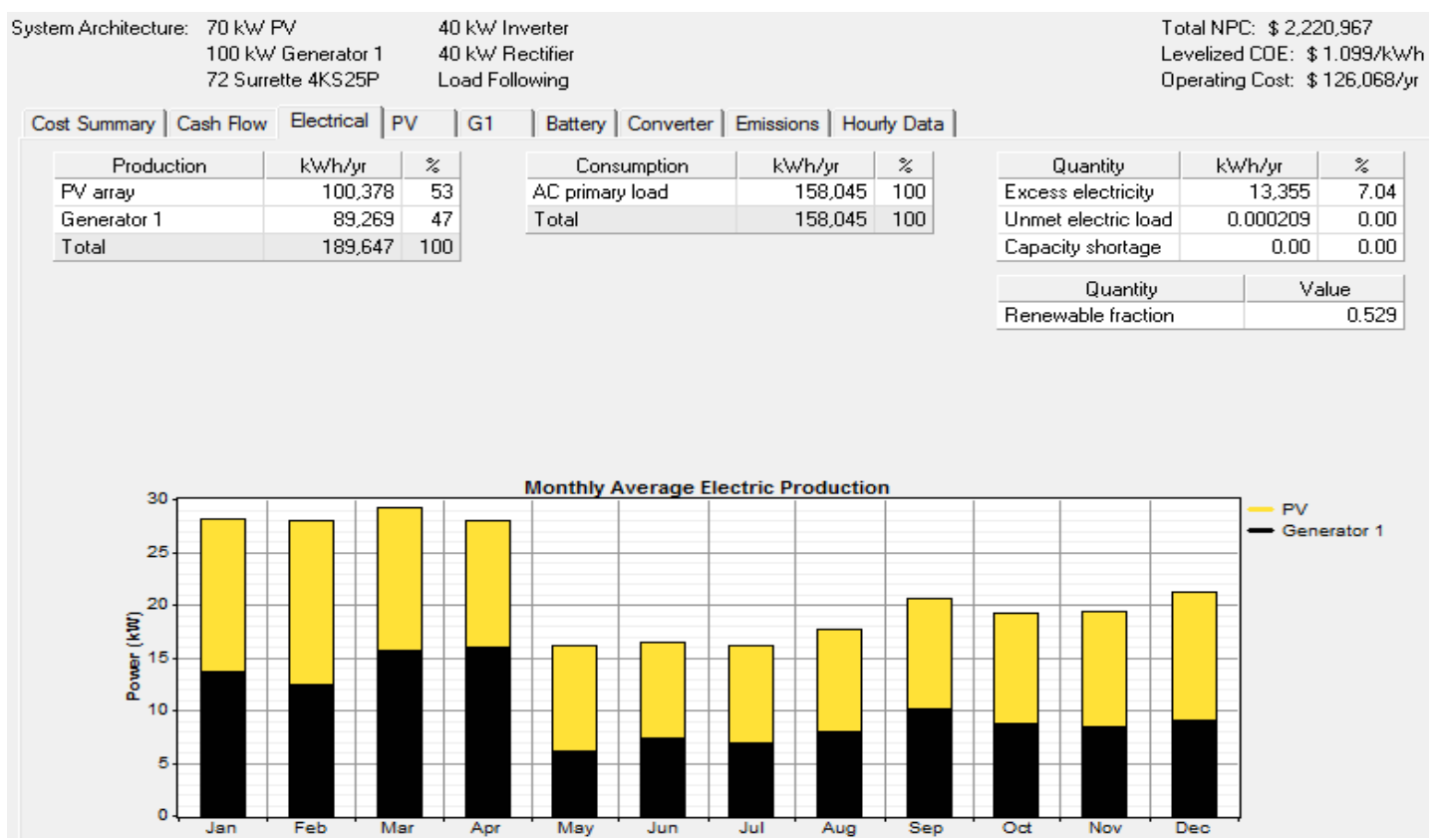

Figure 9. Monthly average electricity production for PV hybrid system

Performance simulation of the integration of hybrid stand-alone photovoltaic... (Shahril Irwan Sulaiman) 


\section{CONCLUSION}

The performance evaluation of the integration of hybrid SAPV system at Tuba Island, Langkawi was conducted in this study. The study showed that the hybrid SAPV system presented a better solution than the existing stand-alone diesel system for providing electricity at the site. The usage of hybrid SAPV system was expected to reduce the operating cost of more than $50 \%$ while the COE can be reduced by approximately $40 \%$.

\section{ACKNOWLEDGEMENT}

The author would like to thank Green Energy Research Centre (GERC), Universiti Teknologi MARA for assisting the simulation process for this work.

\section{REFERENCES}

[1] E-S. A. Nafeh, "Design and economic analysis of a stand-alone PV system to electrify a remote area household in Egypt”, The Open Renewable Energy Journal, vol. 7, no. 6, pp. 1991-1997, 2017.

[2] Z. Othman, S.I. Sulaiman, I. Musirin, S. Shaari, A.M. Omar and M.Z. Rosselan, "Sizing optimization of hybrid stand-alone photovoltaic system," International Journal on Advanced Science, Engineering and Information Technology, vol. 7, no. 6, pp. 1991-1997, 2017.

[3] Ahmarinezhad, A. Abbaspour Tehranifard, M. Ehsan and M. Fotuhi Firuzabad, "Optimal sizing of stand-alone hybrid system for Ardabil area of Iran," International Journal on Technical and Physical Problems of Engineering, vol. 4, no. 12, pp. 118-125, September 2012.

[4] M. Madziga, A. Rahil and R. Mansoor, "Comparison between three off-grid hybrid systems (solar photovoltaic, diesel generator and battery storage system) for electrification for Gwakwani village, South Africa," Environments, vol. 5, no. 57, pp. 1-21, May 2018.

[5] Al-Karaghouli and L.L. Kazmerski, "Optimization and life-cycle cost of health clinic PV system for a rural area in southern Iraq using HOMER software,” Solar Energy, vol. 84, no. 4, pp. 710-714, 2010.

[6] S. Kirmani, M. Jamil, C. Kumar and M. Jamil Ahmed, "Techno economic feasibility analysis of a stand-alone PV system to electrify a rural area household in India," International Journal of Engineering Science and Technology, vol. 2, no. 10, pp. 5231-5237, 2010.

[7] A.V. Anayochukwu and E.A. Nnene, "Simulation and optimization of photovoltaic/diesel hybrid power generation systems for health service facilities in rural environment," Electronic Journal of Energy \& Environment, vol. 1, no. 1, pp. 57-70, April 2013.

[8] E.O. Diemuodeke, E.O. Agbalagba and M.I. Okorho, "Building integrated hybrid PV-battery-diesel generator energy system for oil producing communities in Niger-delta region of Nigeria," International Journal of Renewable Energy Research, vol. 4, no. 2, pp. 286-293, 2014.

[9] P. Kumar, R. Pukale, N. Kumabhar and U. Patil, "Optimal design configuration using HOMER," Procedia Technology, vol. 24, pp. 499-504, 2016

[10] A.S. Oladeji, O.S. Balogun and S.O. Aliyu, "Use of standalone photovoltaic system for office building: the case study of National Centre for Hydropower Research and Development, Nigeria", Nigeria Journal of Technology, vol. 36, no. 4, pp. 1208-1217, October 2017.

[11] P. Boait, V. Advani and R. Gammon, "Estimation of demand diversity and daily demand profile for off-grid electrification in developing countries," Energy for Sustainable Development, vol. 29, pp. 135-141, 2015.

[12] H. Louie and P. Dauenhauer, "Effects of load estimation error on small-scale off-grid photovoltaic system design, cost and reliability," Energy for Sustainable Development, vol. 34, pp. 30-43, 2016.

[13] R. Meenal, A.I. Selvakumar and E. Rajasekaran, "Review on mathematical models for the prediction of solar radiation," International Journal of Electrical Engineering and Computer Science (IJEECS), vol. 15, no. 1, pp. 5459 , July 2019.

[14] AsiaOneNews, "Paying high prices for diesel," [Online]. Available: http://news.asiaone.com/News/AsiaOne\%2BNews/Malaysia/Story/A1Story20090415-135337.html.

[15] A.H. Al-Hamdani, A.F. Dawood, K.N. Abdullah and S.M.H. Mousaui , "Optimal sizing of photovoltaic systems using HOMER for Baghdad, ” International Journal of Computation and Applied Sciences, vol. 1, no. 2, pp. 1-6, October 2016.

[16] M.R.B. Khan, J. Pasupuleti, J. Al-Fattah and M. Tahmasebi, "Energy management system for PV-battery microgrid based on model predictive control," International Journal of Electrical Engineering and Computer Science (IJEECS), vol. 15, no. 1, pp. 20-25, July 2019.

[17] S. Kebaili and H. Benalla, "Optimal sizing of stand-alone photovoltaic systems: a review," Journal of Electrical Engineering, pp. 1-11, 2015.

[18] M.A. Salam, A. Aziz, A.H.A. Alwaeli and H.A. Kazem, "Optimal sizing of photovoltaic systems using HOMER for Sohar, Oman,” International Journal of Renewable Energy Research, vol. 3, no. 2, pp. 1-7, 2013.

[19] B.U. Kansara and B.R. Parekh, "Penetration of renewable energy resources based dispatch strategies for isolated hybrid systems," International Journal of Electrical and Electronics Engineering Research, vol. 3, no.2, pp. 121130, June 2013. 
[20] S. Mandelli, J. Barbieri, R. Mereu and E. Colombo, "Off-grid systems for rural electrification in developing countries: definitions, classifications and a comprehensive literature review," Renewable and Sustainable Energy Reviews, vol. 58, pp. 1621-1646, 2016.

[21] Soufi, A. Chermitti and N.B. Triki, "Sizing and optimization of a livestock shelters solar stand-alone power system," International Journal of Computer Applications, vol. 71, no.4, pp. 40-47, May 2013.

[22] M. Lokanadham and B. Ramesh, "Optimal sizing of stand-alone photovoltaic systems: a review," International Journal of Latest Engineering and Management Research, pp. 662-671, October 2017.

[23] Tabak, M. Ozkeymak, M.T. Guneser and H.O. Erkol, "Optimization and evaluation of hybrid PV/WT/BM system in different initial costs and LPSP conditions," International Journal of Advanced Computer Science and Applications, vol. 8, no.11, pp. 123-131, 2017.

[24] R. Zailan, S.N. Zaini, M.I.M. Rashid and A.A. Razak, "Feasibility study of standalone PV-wind-diesel energy systems for coastal residential application in Pekan, Pahang," MATEC Web of Conferences, vol. 131, pp. $1-16,2017$.

[25] V.A. Ani, "Design of a reliable hybrid (PV/diesel) power system with energy storage in batteries for remote residential home," Journal of Energy, vol. 2016, pp. 1-16, 2016. 